\title{
Oxidation of Methyl Linoleate Mixed with Methyl Octanoate, Laurate or Palmitate
}

\author{
Tiezheng MA, Tomoko TAKAHASHI, Takashi KOBAYASHI, and Shuji ADACHI ${ }^{\dagger}$ \\ Division of Food Science and Biotechnology, Graduate School of Agriculture, \\ Kyoto University, Sakyo-ku, Kyoto 606-8502, Japan
}

\begin{abstract}
The oxidation process of methyl linoleate mixed with methyl octanoate, laurate or palmitate at the molar ratio of $1: 1$ was measured at $65^{\circ} \mathrm{C}$. Methyl linoleate with methyl octanoate was oxidized most rapidly, and the oxidation of the substrates mixed with methyl laurate and palmitate followed. Methyl linoleate was mixed with methyl laurate at the molar ratios of 1:3, 1:1 and 3:1, and its oxidation processes were measured. The methyl linoleate mixed at the lower ratio (1:3) was the most retarded. The oxidation processes were well simulated based on the kinetic equation of the autocatalytic type in consideration of the independent evaporation of methyl octanoate, laurate or palmitate.
\end{abstract}

Key words: lipid oxidation, kinetics, volatile lipid, methyl linoleate

\section{Introduction}

Lipid oxidation, which occurs during processing, storage and cooking, damages the sensory and nutritional values of foods containing lipids [1]. The oxidation, which is a complicated process including the initiation, propagation and termination steps, was affected by many factors such as temperature, humidity, and the presence of a pro- or antioxidant $[2,3]$. We reported that the presence of saturated or unsaturated fatty acid also affected the oxidation of an unsaturated fatty acid. Addition of a saturated fatty acid of the free or ester form to an unsaturated fatty acid or its ester (substrate) retarded the oxidation of the substrate because the saturated fatty acid or the ester acted as a diluent to decrease the concentration of the substrate [4-6]. The dilution effect of a saturated lipid on the unsaturated one occurred in an oil-in-water emulsion system where droplets of the unsaturated lipid were covered with an emulsifier, the hydrophobic moiety of which was a saturated acyl group [7]. The kinetics for the oxidation of an unsaturated lipid mixed with a saturated lipid was analyzed [4-6] based on the kinetic equation of the autocatalytic type [8-10].

In our previous study on the kinetics of the oxidation at $65^{\circ} \mathrm{C}$ of linoleic acid or methyl linoleate mixed with one of the lauric, myristic and palmitic acids or their methyl esters [4], no volatility of the fatty acids and their

(Received 14 May. 2012: accepted 11 Jun. 2012)

$\dagger$ Fax: 075-753-6285, Email: adachi@kais.kyoto-u.ac.jp methyl esters was assumed. However, there is a possibility that the unsaturated lipid and the coexisting saturated one are volatilized at $65^{\circ} \mathrm{C}$. Especially, methyl esters of fatty acids are prone to evaporation. In this context, the oxidation process of methyl linoleate was re-evaluated in the presence of methyl octanoate, laurate or palmitate in consideration of the volatility of the methyl esters.

\section{Materials and Methods}

\subsection{Materials}

Methyl linoleate (purity, $>95 \%$ ) was purchased from Tokyo Chemical Industry (Tokyo, Japan). Methyl octanoate $(>98 \%)$, methyl laurate $(>98 \%)$, and methyl palmitate (>95\%) were purchased from Wako Pure Chemical Industries (Osaka, Japan).

\subsection{Oxidation of methyl linoleate}

For the oxidation of methyl linoleate in a singlecomponent system, $2 \mathrm{~g}$ of methyl linoleate was dissolved in $10 \mathrm{~mL}$ of methanol. Fifty microliters of the solution was placed using a micropipette in a flat-bottomed glass cup $(1.5 \mathrm{~cm}$ i.d. and $3.0 \mathrm{~cm}$ height); then the methanol was removed under reduced pressure. About 80 cups were placed in a plastic container. Air was allowed to flow at $5 \mathrm{~mL} / \mathrm{min}(0.03 \mathrm{~cm} / \mathrm{min})$ into the container after passage through a column packed with silica gel. The rate of oxygen supplied by the air flow was sufficiently higher than that of oxygen consumed by the oxidation of methyl linoleate. The desic- 
cator was stored in a DN-400 oven (Yamato Scientific, Tokyo, Japan) at $65^{\circ} \mathrm{C}$. Periodically, a cup was removed, and $1 \mathrm{~mL}$ of $0.01 \mathrm{~mol} / \mathrm{L}$ methyl myristate was added to the cup as the internal standard in gas chromatographic analysis. The unoxidized methyl linoleate was determined by subjecting $1 \mu \mathrm{L}$ of the mixture to a Shimadzu GC-2014AFsc gas chromatograph (Kyoto, Japan) equipped with a hydrogen flame-ionization detector and a DB-1 column (J \& W Scientific, Santa Clara, CA, USA). The inner diameter and the length of the column were $0.25 \mathrm{~mm}$ and $30 \mathrm{~m}$, respectively. The analytical conditions were a column temperature of $230^{\circ} \mathrm{C}$, injection temperature of $260^{\circ} \mathrm{C}$, detector temperature of $280^{\circ} \mathrm{C}$ and $\mathrm{N}_{2}$ as the carrier gas at a flow rate of $168 \mathrm{~mL} / \mathrm{min}$. The ratio of the amount of methyl linoleate to that of methyl myristate was obtained from the areas under their peaks. The fraction of the unoxidized substrate was calculated from the ratio.

Methyl linoleate was mixed with methyl octanoate, methyl laurate or methyl palmitate to produce a weight of $2 \mathrm{~g}$ at a molar ratio of 1:1 in $10 \mathrm{~mL}$ of methanol in order to measure the oxidation processes of methyl linoleate in a mixed system. The oxidation of methyl linoleate mixed with methyl laurate at molar ratios of $1: 3$ and $3: 1$ was also measured. Other procedures were the same as those above-mentioned for the oxidation in the single-component system.

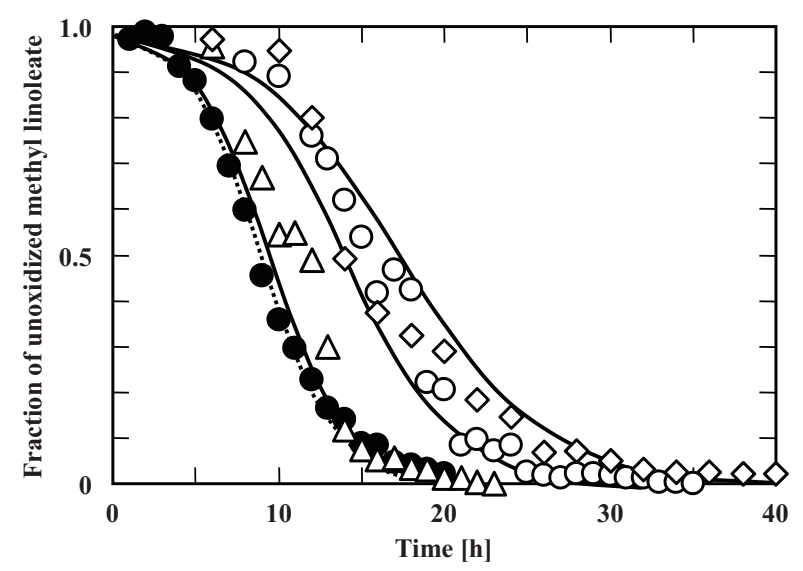

Fig. 1 Oxidation processes at $65^{\circ} \mathrm{C}$ of methyl linoleate mixed with $(\triangle)$ methyl octanoate, $(\bigcirc)$ methyl laurate and $(\diamond)$ methyl palmitate at the molar ratio of $1: 1$. The solid curves were calculated for the oxidation of methyl linoleate mixed with the methyl fatty acid esters in consideration of both the dilution of methyl linoleate with the esters and the evaporation of the esters. The closed circle (0) and dotted curve indicate the observed and calculated oxidation processes, respectively, of methyl linoleate alone.

\subsection{Additivity in volume of fatty acid esters}

In order to measure the density of methyl octanoate, methyl laurate or methyl palmitate, $0.5 \mathrm{~g}$ of the methyl ester was put into a $10-\mathrm{mL}$ graduated cylinder, which had been calibrated using distilled water. The cylinder was immersed in a water-bath kept at $25^{\circ} \mathrm{C}$ for methyl octanoate and laurate or $35^{\circ} \mathrm{C}$ for methyl palmitate for 10 min, and then the volume was read. A further $0.5 \mathrm{~g}$ of the methyl ester was added to the cylinder. The same operations were repeated until $2.5 \mathrm{~g}$ of the methyl ester was added.

One gram of methyl linoleate had been put in the graduated cylinder, and $0.5 \mathrm{~g}$ of methyl octanoate, methyl laurate or methyl palmitate was added to the cylinder. The mixture was mixed magnetically at $25^{\circ} \mathrm{C}$ or $35^{\circ} \mathrm{C}$ for 10 min, and its volume was read. At every $0.5 \mathrm{~g}$ of methyl ester added, the volume was read until $2.5 \mathrm{~g}$ of the methyl ester was added.

\subsection{Volatility of fatty acid ester}

Methyl octanoate $(16.96 \mathrm{mg})$, methyl laurate (17.40 $\mathrm{mg})$, methyl palmitate $(21.05 \mathrm{mg}$ ) or methyl linoleate $(22.13 \mathrm{mg})$ was put in a $6 \mathrm{~mm} \varphi \times 2.5 \mathrm{~mm}$ aluminum cell, and the weight change was measured at $65^{\circ} \mathrm{C}$ under flowing nitrogen gas at a rate of $20 \mathrm{~mL} / \mathrm{min}$ using a TGA$50 \mathrm{H}$ thermogravimeter (Shimadzu, Kyoto, Japan).

Methyl linoleate and methyl laurate were mixed to produce the molar ratio of $1: 3,1: 1$ or $3: 1$, and the mixture

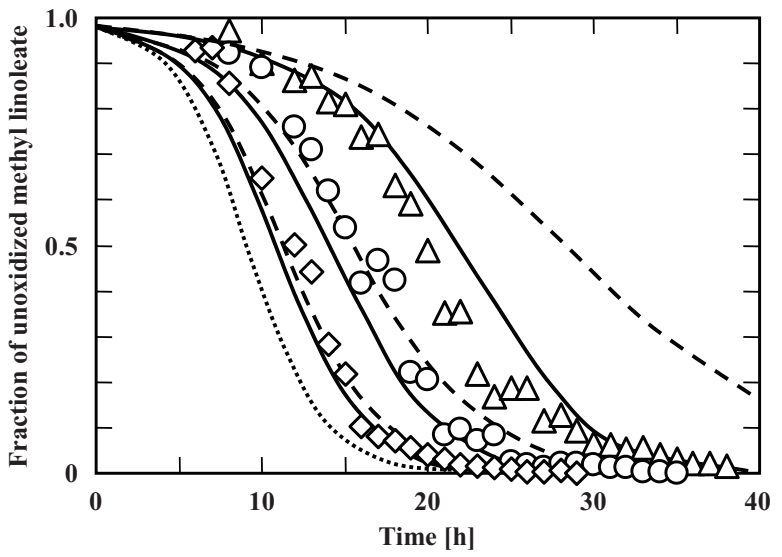

Fig. 2 Oxidation processes at $65^{\circ} \mathrm{C}$ of methyl linoleate mixed with methyl laurate at the molar ratios of $(\triangle) 1: 3$, ( $\bigcirc) 1: 1$ and $(\diamond)$ 3:1. The data for the ratio of $1: 1$ are the same as those in Fig. 1. The dotted curve is the oxidation process calculated for methyl linoleate alone. The solid curves were calculated in consideration of both the dilution of methyl linoleate with methyl laurate and the evaporation of the methyl laurate, while the broken curves were calculated taking only the dilution of methyl linoleate by the methyl laurate into consideration. 
was put in the glass cups. The cups were held in the plastic container at $65^{\circ} \mathrm{C}$ under flowing nitrogen gas at $5 \mathrm{~mL} /$ min. A cup was removed and the amount of remaining methyl laurate was determined by gas chromatography as above-mentioned. It was also confirmed by determining the amount of unoxidized methyl linoleate that no oxidation of methyl linoleate occurred.

\section{Results and Discussion}

\subsection{Oxidation of methyl linoleate}

Figure 1 shows the oxidation processes of methyl linoleate mixed with methyl octanoate, laurate or palmitate at the molar ratio of $1: 1$ as well as the oxidation process of methyl linoleate alone. Methyl linoleate without any additive was most rapidly oxidized. The oxidation of methyl linoleate mixed with methyl octanoate was slightly retarded compared to that of methyl linoleate alone. The reason for the slight difference in the oxidation process between methyl linoleate alone and methyl linoleate mixed with methyl octanolate will be discussed later based on the volatility of methyl octanoate. The addition of methyl laurate or palmitate to methyl linoleate largely retarded the oxidation of methyl linoleate. Because the molar volume is larger in the order of methyl palmitate, laurate and octanoate, the concentration of methyl linoleate was lower in its equimolar mixures with methyl palmitate, laurate and octanoate in this order. The lower concentration of methyl linoleate would retard its oxidation more.

The oxidation processes of methyl linoleate mixed with methyl laurate at the molar ratios of $1: 3$ and $3: 1$ were also measured (Fig. 2). The oxidation process of methyl linoleate mixed with methyl laurate at the molar ratio of $1: 1$, which has been shown in Fig. 1, is also shown in Fig. 2 in order to facilitate understanding the effect of the molar ratio on the oxidation of methyl linoleate. Methyl linoleate was more slowly oxidized at the higher molar ratio of methyl laurate to methyl linoleate. Because the concentration of methyl linoleate in its mixure with methyl laurate was lower at the higher molar ratio, the slower oxidation of methyl linoleate at the higher molar ratio would be ascribed to the dilution effect by methyl laurate [4-6].

\subsection{Additivity in volume}

The densities of methyl linoleate, octanoate and laurate at $25^{\circ} \mathrm{C}$ were estimated to be $835.3,879.2$ and 861.2 $\mathrm{g} / \mathrm{L}$, respectively, in their single-component systems.
The density of methyl palmitate at $35^{\circ} \mathrm{C}$ was also estimated to be $839.8 \mathrm{~g} / \mathrm{L}$. The volume, $\mathrm{V}$, of methyl linoleate mixed with methyl octanoate, laurate or palmitate is calculated by Eq. (1) if the additivity in the volume holds.

$$
V=\frac{w_{\mathrm{ML}}}{\rho_{\mathrm{ML}}}+\frac{w_{\mathrm{MS}}}{\rho_{\mathrm{MS}}}
$$

where $w$ and $\rho$ are the weight and density, and the subscripts, ML and MS, indicate methyl linoleate and methyl ester of saturated fatty acid (methyl octanoate, laurate or palmitate). The densities of methyl linoleate, octanoate, laurate and palmitate at $65^{\circ} \mathrm{C}$ were assumed to be 801.9 , $844.0,826.8$ and $806.2 \mathrm{~g} / \mathrm{L}$, respectively, with the help of the temperature dependence on density of some methyl esters of fatty acids [11].

The observed volumes of methyl linoleate mixed with methyl esters of saturated fatty acids, $V_{\text {obs}}$, are plotted against the volumes calculated by Eq. (1), $V_{\text {cal }}$, in Fig. 3. The plots lie on a diagonal line, indicating that the additivity in volume holds.

\subsection{Volatility of fatty acid ester}

No decrease in weight was observed for methyl linoleate at $65^{\circ} \mathrm{C}$ under flowing nitrogen gas. The decrease in methyl octanoate, laurate or palmitate at $65^{\circ} \mathrm{C}$ was observed as a function of time. The fractions of evaporated methyl ester, which is calculated by $\left(n_{\mathrm{MS} 0}-n_{\mathrm{MS}}\right) /$ $n_{\mathrm{MS} 0}$ where $n_{\mathrm{MS} 0}$ and $n_{\mathrm{MS}}$ are the initial moles of methyl ester and that at any time $t$, are plotted against $t$ in dou-

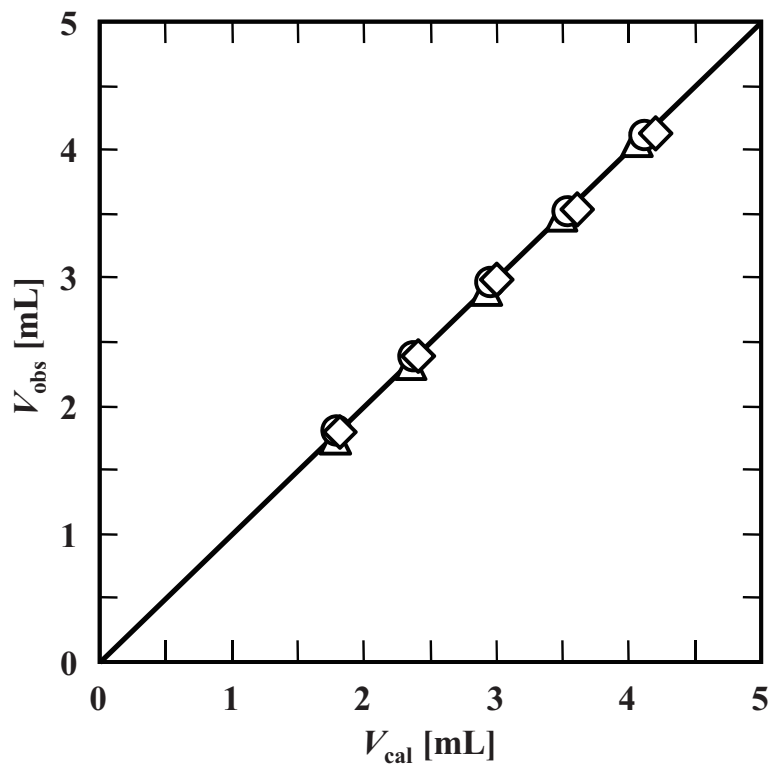

Fig. 3 Additivity in volume between methyl linoleate and $(\triangle)$ methyl octanoate, $(\bigcirc)$ methyl laurate and $(\diamond)$ methyl palmitate. 


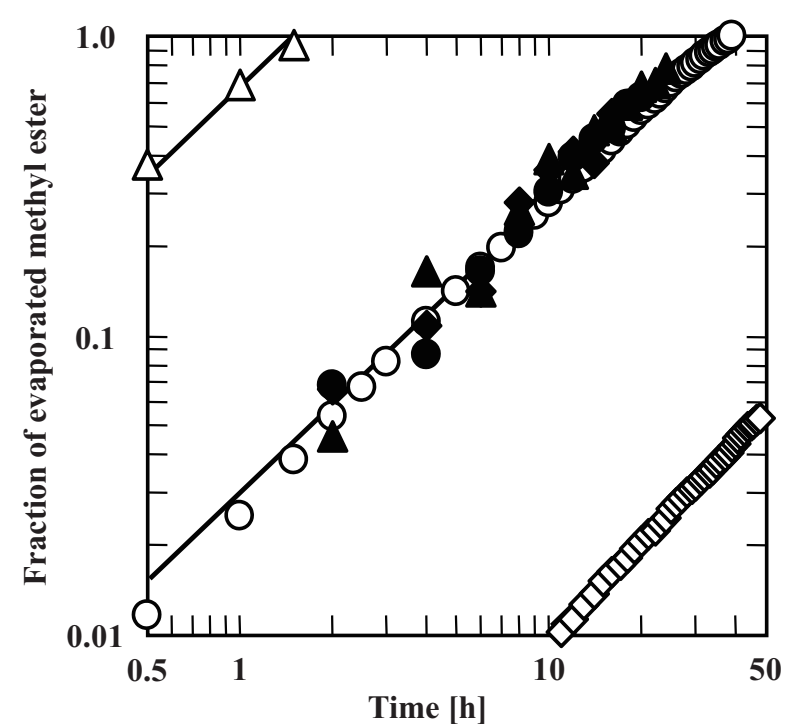

Fig. 4 Evaporation at $65^{\circ} \mathrm{C}$ of $(\triangle)$ methyl octanoate, $(\bigcirc)$ methyl laurate and $(\diamond)$ methyl palmitate in their single-component system, and that of methyl laurate mixed with methyl linoleate at the molar ratios of (४) 3:1 (methyl linoleate: methyl laurate), $(\bullet)$ 1:1 and $(\diamond)$ 3:1.

ble logarithmic chart (Fig. 4). The plots for methyl ester alone lie on a curve with a slope of unity, indicating that the fraction is proportional to the time. Because the fractions of methyl laurate mixed with methyl linoleate at various molar ratios also lie on the line for methyl laurate alone and the molar ratio of methyl laurate to methyl linoleate did not affect the evaporation, it would appear that methyl laurate was evaporated independently of the presence of methyl linoleate. Therefore, the amount of remaining methyl ester, $n_{\mathrm{MS}}$, is expressed as the function of $t$ by the following equation:

$$
n_{\mathrm{MS}}=n_{\mathrm{MS} 0}\left(1-k_{\mathrm{ev}} t\right)
$$

where $k_{\mathrm{ev}}$ is the rate constant for the evaporation, and the $k_{\mathrm{ev}}$ values were evaluated to be $0.685,0.0279$ and 0.00117 $\mathrm{h}^{-1}$ for methyl octanoate, laurate and palmitate, respectively.

\subsection{Oxidation kinetics for methyl linoleate in the mixed system}

The whole process for the oxidation of an $n-6$ fatty acid or its ester, such as methyl linoleate, could be expressed by the kinetic equation of the autocatalytic type for both single-compoment and mixed system $[4,8,9]$.

$$
d C_{\mathrm{ML}} / d t=-k_{\mathrm{ox}} C_{\mathrm{ML}}\left(C_{\mathrm{MLt}}-C_{\mathrm{ML}}\right)
$$

where $C_{\mathrm{ML}}$ is the concentration of unoxidized methyl lineleate, $C_{\mathrm{MLt}}$ is the total concentration of unoxidized and oxidized substrates, and $k_{\mathrm{ox}}$ is the rate constant.

For the oxidation of methyl linoleate alone, Eq. (3) can be rewritten as follows:

$$
d Y / d t=-k_{\mathrm{Y}} Y(1-Y)
$$

where $Y\left(=C_{\mathrm{ML}} / C_{\mathrm{ML}}\right)$ is the fraction of unoxidized substrate, and $k_{\mathrm{Y}}$ is the rate constant and is related to $k_{\mathrm{ox}}$ by Eq. (5).

$$
k_{\mathrm{Y}}=k_{\mathrm{ox}} C_{\mathrm{MLt}}
$$

Equation (4) can be solved under the initial condition of $Y=Y_{0}$ at $t=0$ as follows:

$$
Y=\frac{1}{1+\exp \left\{k_{\mathrm{Y}} t+\ln \left[\left(1-Y_{0}\right) / Y_{0}\right]\right\}}
$$

where $Y_{0}$ is the parameter corresponding to the initial fraction of unoxidized methyl linoleate. The $k_{\mathrm{Y}}$ and $Y_{0}$ values, by which the calculated $Y$ values were best-fitted to the experimental ones, were estimated to be $0.435 \mathrm{~h}^{-1}$ and 0.981, respectively, using the Solver of Microsoft Excel $^{\circledR}$. The calculated process is given by the dotted curve in both Figs. 1 and 2.

For the oxidation of methyl linoleate mixed with methyl octanoate, laurate or palmitate, Eq. (3) can be rewritten as follows:

$$
d n_{\mathrm{ML}} / d t=-k_{\mathrm{OX}} n_{\mathrm{ML}}\left(n_{\mathrm{MLt}}-n_{\mathrm{ML}}\right) / V
$$

where $n_{\mathrm{ML}}$ and $n_{\mathrm{MLt}}$ are the moles of unoxidized methyl linoleate and the total moles of unoxidized and oxidized substrates. As mentioned above, the volume, $V$, changes with time because of the evaporation of methyl octanoate, laurate or palmitate and is calculated by the following equations:

$$
\begin{aligned}
V & =\frac{n_{\mathrm{MLt}} M_{\mathrm{ML}}}{\rho_{\mathrm{ML}}}+\frac{n_{\mathrm{MS} 0}\left(1-k_{\mathrm{ev}} t\right) M_{\mathrm{MS}}}{\rho_{\mathrm{MS}}} & \left(t<t_{\mathrm{ev}}\right)(8 \mathrm{a}) \\
& =\frac{n_{\mathrm{MLt}} M_{\mathrm{ML}}}{\rho_{\mathrm{ML}}} & \left(t \geq t_{\mathrm{ev}}\right)(8 \mathrm{~b})
\end{aligned}
$$

where $M$ is the molecular mass, and $t_{\mathrm{ev}}$ is the time when all of the methyl ester of saturated fatty acid is evaporated and is calculated by

$$
t_{\mathrm{ev}}=1 / k_{\mathrm{ev}}
$$

The oxidation processes of methyl linoleate mixed with methyl octanoate, laurate or palmitate were calculated by solving Eqs. (7) and (8) simultaneously as shown by the solid curves in Figs. 1 and 2. The curves coincided with 
the experimental results.

Because methyl octanoate was evaporated in the early stage of the process $\left(t_{\mathrm{ev}}=1.46 \mathrm{~h}\right)$, methyl linoleate mixed with methyl octanoate was oxidized similarly to the substrate alone (Fig. 1). The dilution effect by methyl palmitate was significant because of the low volatility of methyl palmitate and the oxidation of methyl linoleate was largely retarded.

Under the assumption of no volatilization of methyl laurate, the oxidation processes of methyl linoleate mixed with methyl laurate at various molar ratios were calculated and are shown by the broken curves in Fig. 2 . The difference between the solid and broken curves was small at the molar ratios of $3: 1$ and $1: 1$, while the difference was large at the ratio of $1: 3$. The broken curve for the ratio of 1:3 was far from the experimental results. This fact indicates that the evaporation of methyl ester of a saturated fatty acid should be considered to exactly predict the oxidation process of an unsaturated fatty acid mixed with the ester.

\section{References}

1) E. N. Frankel; Lipid oxidation. Progr. Lipid Res., 19, 1-22 (1980).

2) T. P. Labuza; Kinetics of lipid oxidation in foods. Crit. Rev. Food Technol., 2, 355-404 (1973).

3) M. G. Simic, S. V. Jovanovic, E. Niki; Mechanisms of lipid oxidative processes and their inhibition. In "Lipid oxidation in food (ACS symposium series 500)", A. J. St. Angelo ed., American Chemical Society, 1992, pp. 14-32.

4) E. Ishido, Y. Minemoto, S. Adachi, R. Matsuno; Oxidation of linoleic acid and methyl linoleate mixed with saturated fatty acid or its methyl ester. Lebensm.-Wissens. u. Technol., $\mathbf{3 4}$ 234-238 (2001)

5) E. Ishido, Y. Minemoto, S. Adachi, R. Matsuno; Oxidation of polyunsaturated acylglycerol mixed with saturated or unsaturated acylglycerol. Food Sci. Technol. Res., 8, 353-356 (2002).

6) E. Ishido, S. Adachi, Y. Minemoto, R. Matsuno; Kinetic expression for the oxidation of linoleic acid and arachidonic acid esters in their mixed system. Biosci. Biotechnol. Biochem., 66, 73-77 (2002).

7) H. Imai, T. Maeda, M. Shima, S. Adachi; Oxidation of methyl linoleate in $\mathrm{O} / \mathrm{W}$ micro- and nanoemulsion systems. J. Am. Oil Chem. Soc., 85, 809-815 (2008).

8) S. Özilgen, M. Özilgen; Kinetic model on lipid oxidation in foods. J. Food Sci., 55, 498-501, 536 (1990).

9) S. Adachi, T. Ishiguro, R. Matsuno; Autoxidation kinetics for fatty acids and their esters. J. Am. Oil Chem. Soc., 72, 547-551 (1995).

10) Y. Minemoto, E. Ishido, S. Adachi, R. Matsuno; Autoxidation kinetics for polyunsaturated acylglycerols. Food Sci. Technol. Res., 5, 104-107 (1999).

11) "Handbook of Oil Chemistry (Yukagaku Binran) 4th ed.", Japan Oil Chemists' Society ed., Maruzen, 2001, p.255. 


\title{
和文要約
}

\section{オクタン酸メチル，ラウリン酸メチルまたは パルミチン酸メチルを混合したリノール酸メチルの酸化}

\author{
馬 鉄鋝, 高橋朋子, 小林敬, 安達修二 ${ }^{\dagger}$ \\ 京都大学大学院農学研究科食品生物科学専攻
}

脂質が酸化すると異臭を生成し, 食品としての価值を 失うとともに，酸化生成物が人体にとって有害な場合も あるため，脂質を含有する食品ではその酸化を抑制する ことが大切である，脂質の酸化は，よく知られているよ うに，開始，連鎖抏よび停止の各過程を経て進行する複 雑な反応であり，多くの因子がその速度に影響する [1-3]，筆者らは，単一成分のバルク系に打ける n-6 系 不飽和脂肪酸またはそれらのエステルの全酸化過程は自 触媒型の速度式で表現できることを報告した [8-10]. 一 方，脂質は単一の成分として存在することは少なく，多 くの場合は複雑な組成をもつ混合物である。そのような 系のモデルとして，飽和脂肪酸またはそのエステルを添 加した不飽和脂肪酸またはそのエステル (基質と表記) の酸化速度について検討し，飽和脂肪酸またはそのエス テルが基質を希釈する効果により，基質の酸化が遅延さ れることを示した [4-6]. O/W エマルション系に打いて も, 乳化剂の疎水部が油滴中に入り込み基質を希釈する ので，酸化が遅くなることを示した。とくに，乳化刋の 疎水部による希釈の効果が顕在化しやすいナノエマル ションでその効果が顕著であることを示した [7].

上記の報告では，飽和脂肪酸またはそのエステルは揮 発しないと仮定して解析した。しかし，ガスクロマトグ ラフィに扎いて脂肪酸は揮発しやすいメチルエステルに 変換してから定量されるように，基質の酸化過程の測定 中に脂肪酸エステルが揮発している可能性がある. とく に，基質を短時間に酸化させるために高温で反応する加 速試験ではその可能性が高い.
そこで本研究では，炭素数が異なり揮発のしやすさが 異なると考元られるオクタン酸メチル, ラウリン酸メチ ルまたはパルミチン酸メチルを混合したリノール酸メチ ルの $65^{\circ} \mathrm{C} に$ 打ける酸化過程を測定した。また，オクタン 酸メチル, ラウリン酸メチルまたはパルミチン酸メチル の単一成分系での揮発過程打よびリノール酸メチルに 種々のモル比で添加したリウリン酸メチルの揮発過程を 測定した.リノール酸メチルに対して 1:1 のモル比でオ クタン酸メチル，ラウリン酸メチルまたはパルミチン酸 メチルを添加した場合には, 揮発しやすいオクタン酸メ チルを添加した場合が最も速く酸化され, ラウリン酸メ チル，パルミチン酸メチルの順で酸化が遅延された。 ま た,リノール酸メチルに対してラウリン酸メチルを $1: 3$, 1:1 または 3:1 のモル比で添加した場合には, 添加するラ ウリン酸メチルの割合が多いほど基質の希釈度が大きく なり酸化が遅延された。リノール酸メチルに飽和脂肪酸 メチルを添加した系に打いて, リノール酸メチルの存在 に影響されることなく飽和脂肪酸は揮発すると考え, 残 存する飽和脂肪酸メチルによる希䣋効果を考慮した自触 媒型酸化反応速度式を適用することにより，実測值を良 好に表現できた。

実際の脂質は多くの種類のトリアシルグリセロール の混合物であるため, ここで得られた知見が直ちに適 用できるわけではないが，比較的揮発しやすい脂質を 含有する脂質の酸化過程を考える際には，揮発による 体積の変化に伴う基質濃度の変化を考慮すべきである ことを示した。 